\title{
EFIKASI EKSTRAK DAUN MENGKUDU TERHADAP MORTALITAS LARVA Crocidolomia binotalis Zell.
}

\author{
Silvia Setiawati, Rosma Hasibuan, Nuryasin \& Purnomo \\ Jurusan Agroteknologi, Fakultas Pertanian, Universitas Lampung \\ Jl. Prof. Soemantri Brojonegoro, No. 1 Bandar Lampung 35145 \\ Email: Silvia.bintidarius@yahoo.com
}

\begin{abstract}
ABSTRAK
Kubis (Brassica oleracea L.) merupakan salah satu jenis tanaman sayuran yang mempunyai nilai gizi yang tinggi dan mengandung beberapa zat yang sangat bermanfaat bagi tubuh. Serangan hama merupakan salah satu kendala dalam budidaya tanaman kubis. Hama penting tanaman kubis adalah Crocidolomia binotalis. Tujuan penelitian ini adalah untuk mengetahui pengaruh ekstrak daun mengkudu terhadap mortalitas larva $C$. binotalis dan mengetahui tingkat toksisitas ekstrak daun mengkudu dalam membunuh larva C. binotalis. Penelitian ini disusun dalam Rancangan Acak Kelompok (RAK) dengan perlakuan konsentrasi ekstrak 1\%,2\%,3\%,4\% dan 5\%. Insektisida nabati yang digunakan adalah ekstrak daun mengkudu. Hasil penelitian menunjukkan bahwa ekstrak daun mengkudu mampu membunuh larva C. binotalis. Ekstrak daun mengkudu konsentrasi 1\%,2\%,3\%, 4\% dan 5\% berpengaruh nyata terhadap mortalitas Crocidolomia binotalis. Toksisitas daun mengkudu yang dinyatakan dengan $\mathrm{LC}_{50}$ pada 36 jam setelah aplikasi adalah $0,98 \%$, sedangkan toksisitas daun mengkudu yang dinyatakan dalam $\mathrm{LT}_{50}$ pada konsentrasi $1 \%$ adalah $38,89 \mathrm{jam}, 2 \%$ adalah $24,03 \mathrm{jam}, 3 \%$ adalah $16,64 \mathrm{jam}, 4 \%$ adalah 19,11 jam dan $5 \%$ adalah 11,84 jam setelah aplikasi.
\end{abstract}

Kata Kunci: Crocidolomia binotalis, ekstrak daun mengkudu, kubis

\section{PENDAHULUAN}

Kubis (Brassica oleracea L.) merupakan satu jenis tanaman sayuran yang mempunyai nilai gizi yang tinggi dan mengandung beberapa zat yang sangat bermanfaat bagi tubuh, diantaranya vitamin dan mineral yang dapat membantu sistem pencernaan dan menetralkan zat asam (Pracaya,2006). Kubis juga merupakan tanaman sayuran yang banyak dibudidayakan oleh petani di Indonesia. Selain rasanya enak tanaman kubis mengandung vitamin $\mathrm{B}$ dan $\mathrm{C}$ sehingga baik untuk kesehatan (Sunardi, 2001).

Untuk menghasilkan produksi yang maksimal pada budidaya tanaman kubis perlu memperhatikan persiapan penanaman sampai pengelolaan pasca panen. Tanaman kubis yang dibudidayakan dengan baik mampu menghasilkan 30-40 ton/ha. Namun untuk menghasilkan produksi maksimal ada kendala yang dihadapi seperti serangan hama ulat kubis (Crocidolomia binotalis Zell.). Di Malaysia apabila tidak menggunakan insektisida, hama dapat menyebabkan kehilangan hasil $87,5 \%$, sedangkan di Indonesia kehilangan hasil bisa mencapai 100\% (Cahyono, 1995).

Dalam budidaya kubis terdapat beberapa kendala yang harus diatasi yakni adanya kehadiran OPT (Organisme Pengganggu Tanaman) yang merupakan faktor pembatas hasil dari tanaman sayuran (Suryaningsih dan Hadisoeganda 2004). Salah satu OPT yang dapat merusak tanaman kubis adalah hama ulat krop (Crocidolomia binotalis). Serangga ini merupakan jenis hama yang sangat rakus terutama pada stadium larva. Larva dapat menyerang daun muda dan daun yang tua (Kaswinarni, 2005).

Gejala kerusakan yang disebabkan oleh hama ini sangat khas, yaitu pada daun terbentuk suatu lubang dengan diameter $0,5 \mathrm{~cm}$ sehingga daun menjadi berlubang-lubang. Pada serangan cukup berat, tanaman kubis gagal membentuk krop sehingga gagal panen (Rueda dan Shelton, 2006). Pada umumnya pengendalian hama yang dilakukan oleh para petani lebih mengandalkan penggunaan pestisida sintetik. Jika ditinjau secara ekologi penggunaan pestisida sintetik dapat berdampak negatif terhadap lingkungan (Sembel, 2010). Penggunaan pestisida sintetik yang tidak bijaksana akan merusak lingkungan dan kesehatan manusia. Dalam penerapan di bidang pertanian, pestisida sintetik tidak semuanya mengenai sasaran. Kurang lebih hanya $20 \%$ pestisida mengenai sasaran, sedangkan $80 \%$ lainnya masuk ke dalam tanah (Suryaningsih dan Hadisoeganda, 2004). Pestisida sintetik juga dapat menimbulkan residu pestisida pada bahan yang telah dipanen tersebut (Sembel, 2010). 
Penggunaan pestisida nabati merupakan salah satu cara lain dalam menggantikan peran pestisida kimia. Salah satu tanaman yang dapat dijadikan pestisida nabati adalah tanaman mengkudu (Morinda citrifolia). Tanaman mengkudu merupakan jenis tanaman yang berpotensi sebagai insekisida botani yang digunakan untuk mengendalikan beberapa organisme penggangu tanaman (OPT). Daun mengkudu yang mengandung saponin, flavonoid dan polifenol dapat bersifat racun pada serangga. Ekstrak daun mengkudu yang dicampur dengan bahan tambahan lain mampu menghambat pertumbuhan larva $C$. binotalis menjadi pupa $C$. binotalis (Kardinan, 2004).

Berdasarkan uraian di atas, informasi tentang toksisitas menggunakan ekstrak daun mengkudu terhadap larva $C$. binotalis sangat diperlukan, maka dilakukan penelitian mengenai efikasi ekstrak daun mengkudu terhadap mortalitas larva $C$. binotalis. Penelitian ini bertujuan untuk mengetahui pengaruh ekstrak daun mengkudu terhadap mortalitas larva $C$. binotalis, mengetahui tingkat toksisitas ekstrak daun mengkudu dalam membunuh larva $C$. binotalis

\section{BAHAN DAN METODE}

Penelitian ini dilakukan pada bulan Maret 2017 sampai dengan bulan Juli 2017 di Laboratorium Proteksi Tanaman Jurusan Agroteknologi Fakultas Pertanian Universitas Lampung. Bahan yang digunakan pada penelitian ini yaitu larva Crocidolomia binotalis, daun mengkudu, air, etanol $70 \%$, daun kubis, madu $10 \%$ dan detergent. Sedangkan Alat yang digunakan pada penelitian ini adalah alat penumbuk (blender), stoples dengan ukuran tinggi $15 \mathrm{~cm}$ dan diameter $15 \mathrm{~cm}$, handsprayer modifikasi dengan volume $10 \mathrm{ml}$, wadah pemeliharaan, gelas ukur $500 \mathrm{ml}$, erlenmeyer, kain kasa, kuas, tali, kapas, gunting, rotary evaporator pada suhu $45^{\circ} \mathrm{C}-50^{\circ} \mathrm{C}$ dengan rotasi permenit $100 \mathrm{Rpm}$, strimin, kertas saring dan alat tulis.

Penelitian ini disusun dalam Rancangan Acak Kelompok (RAK). Rancangan Acak Kelompok ini terdiri atas 6 perlakuan dengan 3 kali ulangan. Dalam percobaan ini, masing-masing perlakuan terdiri atas konsentrasi kontrol $(0 \%), 1 \%, 2 \%, 3 \%, 4 \%$ dan 5\% ekstrak daun mengkudu. Sehingga diperoleh 6 perlakuan x 3 ulangan $=18$ satuan percobaan. Setiap satuan percobaan berisi 10 ekor serangga uji.

A) Pelaksanaan Penelitian

Pembiakan serangga uji. Serangga uji yang digunakan untuk bahan penelitian adalah larva yang dipelihara sendiri yang didapat dari pertanaman caisim, kol dan sawi di daerah Gisting, Tanggamus. Larva yang digunakan adalah Crocidolomia binotalis. Larva yang sudah didapat dipelihara di laboratorium dengan cara meletakkan larva di stoples plastik. Crocidolomia binotalis ini dipelihara dengan cara diberi pakan yang ditanam sendiri yaitu daun caisim yang segar. Larva dipelihara sampai bertelur dan sampai telur menetas hinggal menjadi larva intar II.

Penyediaan ekstrak daun mengkudu. Daun mengkudu segar yang sudah disiapkan dicuci hinggga bersih, kemudian daun mengkudu dikering-anginkan selama satu minggu. Setelah kering, daun mengkudu diblender sehingga didapat sebuk halus daun mengkudu. Setelah itu, sebanyak 50 gram serbuk daun mengkudu dimasukkan kedalam gelas ukur dan ditambah detergent sebanyak 0,5 gram, serta dicampur etanol $70 \%$ hingga volume mencapai $500 \mathrm{ml}$. Setelah semua bahan dicampur kemudian dihomogenkan dengan magnetic stirrer selama $1 \mathrm{jam}$. Setelah 1 jam kemudian disaring dengan kertas saring untuk mendapatakan ektrak daun mengkudu. Ampas yang tersisa ditambahkan lagi etanol (70 \%) sebanyak $500 \mathrm{ml}$ kemudian dilakukan hal yang sama dengan cara yang sebelumnya. Setelah didapat ekstrak daun mengkudu maka ekstrak tersebut dirotasi menggunakan rotary evaporator selama 2 jam dengan suhu $45-50{ }^{\circ} \mathrm{C}$ dan dengan kecepatan 100 RPM. Kemudian setelah dirotari, ekstrak tersebut diletakkan pada nampan untuk dikeringanginkan. Setelah kering (selama 1 minggu) ektrak tersebut dikerik sampai menjadi serbuk. Serbuk yang telah jadi tadi dibuat konsentrasi ekstrak dengan konsentrasi $1 \%, 2 \%, 3 \%$, $4 \%$ dan $5 \%$.

Aplikasi insektisida ekstrak daun mengkudu. Aplikasi ekstrak mengkudu dilakukan dengan cara mencampurkan ekstrak mengkudu dengan air, sebagai contoh untuk konsentrasi $1 \%$, ekstrak mengkudu ditimbang sebanyak 0,1 gram kemudian ditambahkan air sebanyak $10 \mathrm{ml}$, untuk konsentrasi $2 \%$, ekstrak mengkudu ditimbang sebanyak 0,2 gram dan ditambah dengan air sebanyak $10 \mathrm{ml}$, selanjutnya sampai $5 \%$. Setelah itu ekstrak yang sudah dicampur dimasukkan kedalam handsprayer yang sudah dimodifikasi dengan volume $10 \mathrm{ml}$. Kemudian disemprotkan langsung pada larva yang ada pada setiap stoples, masing-masing stoples berisi 10 ekor larva instar II. Kemudian stoples ditutup kain strimin, setelah itu dilakukan pengamatan pada seitap jamnya selama 12 jam, kemudian setiap 6 jam sekali setelah 12 jam sampai 24 jam, selanjutnya 12 jam sekali setelah 24 jam sampai larva mati $100 \%$.

B) Pengamatan

Pengamatan dilakukan setiap jam selama 12 jam, selanjutnya setiap 12 jam sampai larva $C$. binotalis menunjukan mortalitas $100 \%$. Variabel yang diamati 
adalah mortalitas dan toksisitas ekstrak daun mengkudu terhadap mortalitas larva $C$. binotalis. Presentase mortalitas dihitung dengan rumus:

$$
\mathrm{M}=\frac{\mathrm{x}}{\mathrm{y}} \times 100 \%
$$

Keterangan :

$\mathrm{M}=$ mortalitas

$\mathrm{x}=$ jumlah serangga yang mati

$\mathrm{y}=$ jumlah serangga uji

Toksisitas ekstrak daun mengkudu. Pengitungan toksisitas dalam Lethal Concentration dan Lethat Time dengan menggunakan analisis probit menggunakan perangkat SAS 9.3.

Analisis Data. Data yang diperoleh kemudian dianalisis ragam. Perbedaan nilai tengah perlakuan diuji dengan Uji Beda Nyata Terkecil (BNT) pada taraf kepercayaan $5 \%$.

\section{HASIL DAN PEMBAHASAN}

Hasil Penelitian. Mortalitas Crocidolomia binotalis. Hasil penelitian menunjukan bahwa perlakuan konsentrasi ekstrak daun mengkudu berpengaruh nyata terhadap mortalitas Crocidolomia binotalis. Analisis statistik dilakukan pada data mortalitas $C$. binotalis setiap 12 jam dari 6 jam setelah aplikasi sampai 18 jam setelah aplikasi, kemudian dilanjutkan pengamatan 6 jam selanjutnya, yaitu pada 18 jam setelah aplikasi sampai
24 jam setelah aplikasi, setelah itu dilakukan pengamatan setiap 12 jam setelah 24 jam setelah aplikasi sampai larva menunjukan mortalitas 100\% (Tabel 2). Hasil sidik ragam menunjukan bahwa perlakuan konsentrasi ekstrak daun mengkudu berpengaruh nyata pada mortalitas larva $C$. binotalis pada $6,18,24,36,48$ dan 60 jam setelah aplikasi (Tabel 1)

Dilihat dari hasil penelitian (Tabel 1) konsentrasi ekstrak daun mengkudu yang baik untuk direkomendasikan kepada petani di lapangan adalah pada konsentrasi 4\%. Pada tabel 2, konsentrasi 4\% pada 36, 48 dan 60 jam setelah aplikasi masing-masing menunjukan angka 80,00; 90,00 dan 93,33. Jika dibandingkan dengan konsentrasi 5\%, mortalitas yang dihasilkan tidak berbeda jauh, maka ekstrak daun mengkudu pada konsentrasi 4\% lebih baik jika ditinjau secara ekonomis.

Data hasil penelitian menunjukan bahwa aplikasi daun mengkudu dengan konsentrasi tertinggi (5\%) dapat menyebabkan kematian $C$. binotalis sebanyak 23\% pada saat 6 jam setelah aplikasi dan mencapai $100 \%$ pada saat 60 jam setelah aplikasi. Sebaliknya, pada konsentrasi terendah (1\%), mortalitas $C$. binotalis adalah $10 \%$ pada saat 6 jam setelah aplikasi dan mencapai $60 \%$ pada 60 jam setelah aplikasi (Gambar $1)$.

Gambar 1. Persentase mortalitas larva $C$. binotalis pada berbagai konsentrasi selama 120 jam. Secara umum, mortalitas larva $C$. binotalis terus meningkat sejalan dengan waktu pengamatan. Keseluruhan 5 taraf konsentrasi yang diuji, pada setiap

Tabel 1. Pengaruh perlakuan konsentrasi ekstrak daun mengkudu terhadap mortalitas larva $C$. binotalis.

\begin{tabular}{ccccccc}
\hline Konsentrasi (\%) & 6 jsa & 18 jsa & 24 jsa & 36jsa & 48 jsa & 60 jsa \\
\hline $0 \%$ & $0,00 \mathrm{c}$ & $0,00 \mathrm{~d}$ & $0,00 \mathrm{~d}$ & $0,00 \mathrm{~d}$ & $0,00 \mathrm{e}$ & $0,00 \mathrm{e}$ \\
$1 \%$ & $10,00 \mathrm{~b}$ & $30,00 \mathrm{c}$ & $46,67 \mathrm{c}$ & $50,00 \mathrm{c}$ & $56,67 \mathrm{~d}$ & $60,00 \mathrm{~d}$ \\
$2 \%$ & $10,00 \mathrm{~b}$ & $43,33 \mathrm{~b}$ & $53,33 \mathrm{c}$ & $66,67 \mathrm{~b}$ & $70,00 \mathrm{c}$ & $73,33 \mathrm{c}$ \\
$3 \%$ & $13,00 \mathrm{~b}$ & $46,67 \mathrm{~b}$ & $53,33 \mathrm{c}$ & $76,67 \mathrm{ab}$ & $80,00 \mathrm{bc}$ & $83,33 \mathrm{~b}$ \\
$4 \%$ & $13,00 \mathrm{~b}$ & $53,33 \mathrm{ab}$ & $66,67 \mathrm{~b}$ & $80,00 \mathrm{ab}$ & $90,00 \mathrm{ab}$ & $93,33 \mathrm{a}$ \\
$5 \%$ & $23,00 \mathrm{a}$ & $63,33 \mathrm{a}$ & $80,00 \mathrm{a}$ & $90,00 \mathrm{a}$ & $93,33 \mathrm{a}$ & $100,00 \mathrm{a}$ \\
\hline f-hitung & $7,57^{* *}$ & $33,57^{* *}$ & $43,77^{* *}$ & $36,69^{* *}$ & $60,05 * *$ & $170,43 * *$ \\
$\mathrm{f}-0.05$ & 3,33 & 3,33 & 3,33 & 3,33 & 3,33 & 3,33 \\
$\mathrm{f}-0.01$ & 5,64 & 5,64 & 5,64 & 5,64 & 5,64 & 5,64 \\
\hline BNT & 7,43 & 10,33 & 11,02 & 14,73 & 11,98 & 7,43 \\
\hline
\end{tabular}

Keterangan: $* *=$ sangat nyata pada taraf $1 \%$ 
pengamatan 12 jam setelah aplikasi menunjukkan mortalitas serangga uji yang berbeda nyata dengan kontrol ( $0 \%)$. Pada pengamatan 6 jam setelah aplikasi efikasi ekstrak daun mengkudu menunjukkan mortalitas larva $C$. binotalis tertinggi adalah $23 \%$ pada konsentrasi $5 \%$, mortalitas ini nyata lebih tingi apabila dibandingkan dengan perlakuan konsentrasi $4 \%$ yaitu $13 \%$. Pada saat 60 jam setelah aplikasi, persentase mortalitas larva sudah mencapai $100 \%$ yaitu pada konsentrasi $5 \%$, sedangkan

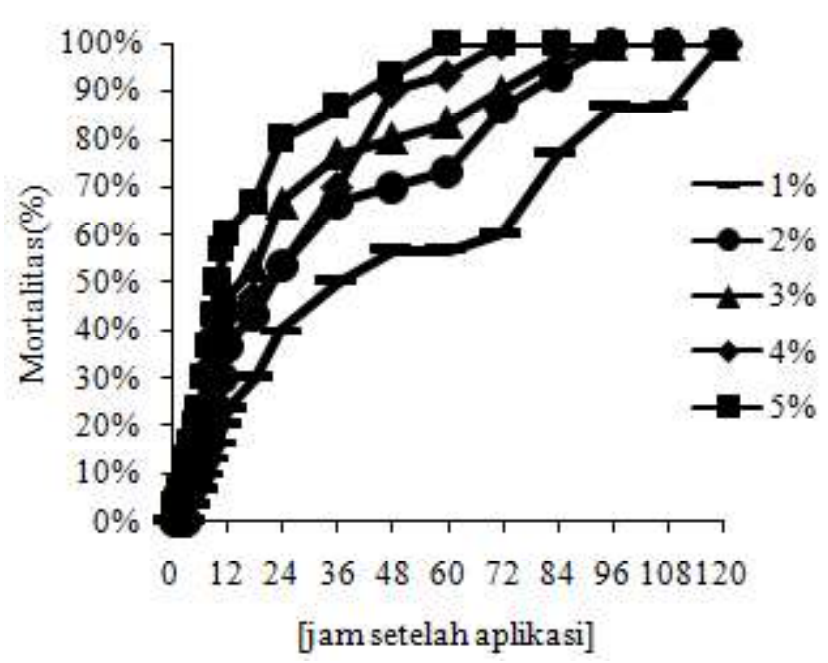

Gambar 1. Persentase mortalitas larva C. binotalis pada berbagai konsentrasi selama 120 jam pada perlakuan konsentrasi $1 \%$ persentase mortalitas menunjukan angka $60 \%$.

Toksisitas Ekstrak Daun Mengkudu Terhadap Crocidolomia binotalis. Hasil pengamatan toksisitas ekstrak daun mengkudu ditetapkan dengan menghitung Lethal Concentration (LC) pada waktu 18 jam setelah aplikasi dengan uji probit menggunakan perangkat SAS. Nilai $\mathrm{LC}_{15}$ pada 18 jam setelah aplikasi adalah $0,37 \%$. Artinya ekstrak daun mengkudu sebersar $0,37 \%$ dapat membunuh larva sebanyak $15 \%$ setelah 18 jam setelah aplikasi. Nilai $\mathrm{LC}_{50}$ pada 18 jam setelah aplikasi menunjukan pada angka 2,90\% dan nilai $\mathrm{LC}_{95}$ pada 18 jam setelah aplikasi adalah $77,52 \%$. Nilai LC yang digunakan untuk menentukan daya racun secara umum adalah $\mathrm{LC}_{50}$. Dengan itu, toksisitas $\mathrm{LC}_{50}$ menunjukan bahwa pada konsentrasi 2,90\% menyebabkan mortalitas serangga uji sebanyak 50\% (Tabel 2).

Selain Lethal Concentration $50\left(\mathrm{LC}_{50}\right)$, daya racun juga dapat diduga dengan Lethal Time $50\left(\mathrm{LT}_{50}\right)$. Nilai $\mathrm{LT}_{50}$ ekstrak daun mengkudu pada konsentrasi $1 \%$ menunjukkan pada angka 38,89 jam dilihat dari angka tersebut, $\mathrm{LT}_{50}$ menunjukan bahwa mortalitas larva $C$. binotalis pada konsentrasi $1 \%$ terjadi pada 38,89 jam setelah aplikasi. Sedangkan pada konsentrasi tertinggi yaitu 5\%, nilai $\mathrm{LT}_{50}$ adalah 11,84 (Tabel 3). Hasil uji probit menunjukkan bahwa nilai $\mathrm{LT}_{50}$ pada ekstrak daun mengkudu semakin rendah dengan meningkatnya konsentrasi ekstrak daun mengkudu. Hal ini

Tabel 2. Hasil analisis probit Lethat Concentration (LC) 18 jam setelah aplikasi ekstrak daun mengkudu terhadap larva $C$. binotalis

\begin{tabular}{cccc}
\hline \multirow{2}{*}{ Probabliltas } & \multirow{2}{*}{ Dugaan } & \multicolumn{2}{c}{ Taraf Kepercayaan 95\% } \\
\cline { 3 - 4 } & & Batas Bawah & Batas Atas \\
\hline 0,15 & 0,37 & 0,09 & 0,66 \\
0,50 & 2,90 & 2,31 & 3,78 \\
0,95 & 77,52 & 29,02 & 29,02 \\
\hline
\end{tabular}

Tabel 3. Hasil analisis probit Lethal Time (LT) 50\% dalam waktu 60 jam setelah aplikasi

\begin{tabular}{cccc}
\hline \multirow{2}{*}{ Perlakuan (\%) } & LT $_{50}$ & \multicolumn{2}{c}{ Taraf Kepercayaan 95\% } \\
\cline { 3 - 4 } & & Batas Bawah & Batas Atas \\
\hline 1 & 38,89 & 33,42 & 46,70 \\
2 & 24,03 & 20,89 & 27,38 \\
3 & 16,64 & 14,11 & 19,11 \\
4 & 19,11 & 14,55 & 23,63 \\
5 & 11,85 & 10,19 & 13,45 \\
\hline
\end{tabular}


menunjukkan bahwa semakin tinggi konsentrasi, maka kemampuan membunuh semakin cepat. (nilai LT semakin rendah).

Pembahasan. Mortalitas larva C. binotalis. Hasil penelitian menunjukkan bahwa ekstrak daun mengkudu efektif membunuh larva Crocidolomia binotalis ditinjau dari segi tingkatan konsentrasi maupun waktu. Hasil penelitian menunjukkan bahwa ekstrak daun mengkudu pada perlakuan $1 \%, 2 \%, 3 \%, 4 \%$ dan $5 \%$ berpegaruh nyata terhadap mortalitas larva $C$. binotalis. Pada perlakuan kontrol $(0 \%)$, larva $C$. binotalis tidak ada yang mati dan dapat berkembang biak secara normal, sedangkan yang menerima perlakuan tidak dapat melaksanakan metamorfosis bahkan mengalami mortalitas sebelum menjadi pupa. Proses kematian (mortalitas) hama akan semakin cepat dengan peningkatan konsentrasi yang digunakan (Natawigena, 1993).

Toksisitas daun mengkudu terhada larva Crocidomolia binotalis. Toksisitas suatu insektisida ditentukan berdasarkan banyaknya serangga uji yang memberikan respon akibat perlakuan suatu insektisida. Pada serangga hama (ukuran tubuh sangat kecil), penentuan toksisitas dinyatakan dalam $\mathrm{LC}_{50}$. Selain itu, daya racun insektisida dapat juga diketahui berdasarkan waktu bekerjanya insektisida untuk membunuh 50\% populasi serangga uji yang sering dinyatakan dengan nilai Lethal Time $\left(\mathrm{LT}_{50}\right)$ (Hasibuan, 2012). Daun mengkudu diketahui memiliki potensi dalam mempengaruhi larva C. binotalis. Hasil nilai $\mathrm{LC}_{50}$ menunjukkan semakin lama waktu setelah aplikasi, maka semakin rendah nilai konsentrasi ekstrak daun mengkudu untuk mempengaruhi serangga uji, sehingga membentuk kurva yang semakin menurun (Gambar 2). Dari data di atas, nilai $\mathrm{LT}_{50}$ dapat dilihat bahwa semakin tinggi konsetrasi,

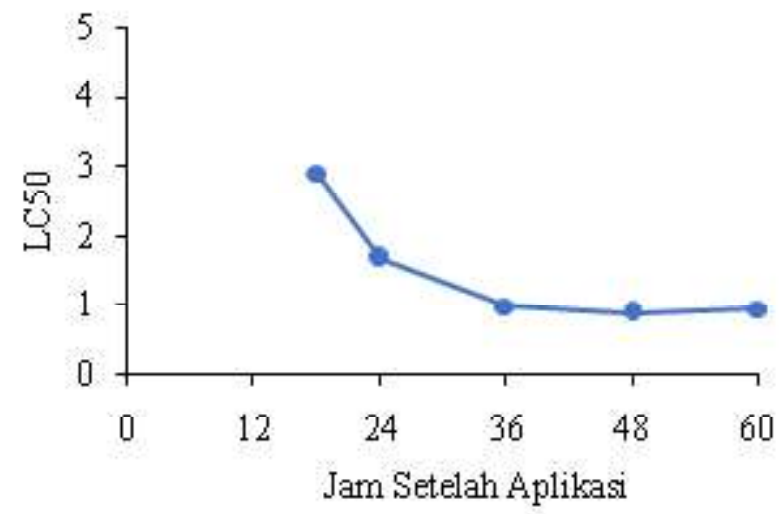

Gambar 2. Nilai Lethal Concentration (LC) 50 Pada Beberapa Jam Setelah Aplikasi Ekstrak Daun Mengkudu terhadap Mortalitas Larva C. binotalis maka waktu yang dibutuhkan untuk membunuh larva C. binotalis sangat cepat, sehingga digambarkan kurva yang semakin menurun (Hasibuan, 2012) (Gambar 3).

Ekstrak daun mengkudu yang diaplikasikan mempengaruhi kematian pada larva $C$. binotalis dikarenakan adanya kandungan senyawa aktif pada ekstrak daun mengkudu. Beberapa senyawa aktif pada daun mengkudu diantaranya adalah saponin, flavonoid, polifenol, triterpene dan tannin (Kardinan, 2004). Daun mengkudu juga mengandung atsiri, alkaloid dan antrakinon (Mursito, 2002). Kandungan minyak atsiri pada daun mengkudu dapat menghasilkan bau dan uap apabila terhirup terus melalui sistem pernapasan. Pada konsentrasi tinggi dapat mengakibatkan kerusakan sehingga dapat menimbulkan kematian pada serangga.

Gejala dan perilaku Crocidolomia binotalis yang terekspose. Beberapa larva $C$. binotalis mengalami gejala serta perilaku yang tidak normal akibat senyawa aktif pada daun mengkudu. Gejala dan perilaku akibat senyawa aktif daun mengkudu pada larva $C$. binotalis yang terlihat adalah larva menjadi kejang, kemudian larva berubah warna menjadi pucat, bahkan ada yang sampai hitam (Gambar 4).

\section{KESIMPULAN}

Ekstrak daun mengkudu dapat menimbulkan mortalitas terhadap larva $C$. binotalis. Semakin tinggi konsentrasi ekstrak daun mengkudu, mengakibatkan waktu kematian semakin cepat dan jumlah kematian yang semakin tinggi pada larva C. binotalis. Aplikasi ekstrak daun mengkudu pada pengamatan 18 jam setelah aplikasi memiliki daya bunuh 50\% serangga uji $\left(\mathrm{LC}_{50}\right)$ pada konsentrasi 2,90\%. Aplikasi ekstrak daun mengkudu memiliki kecepatan membunuh 50\%

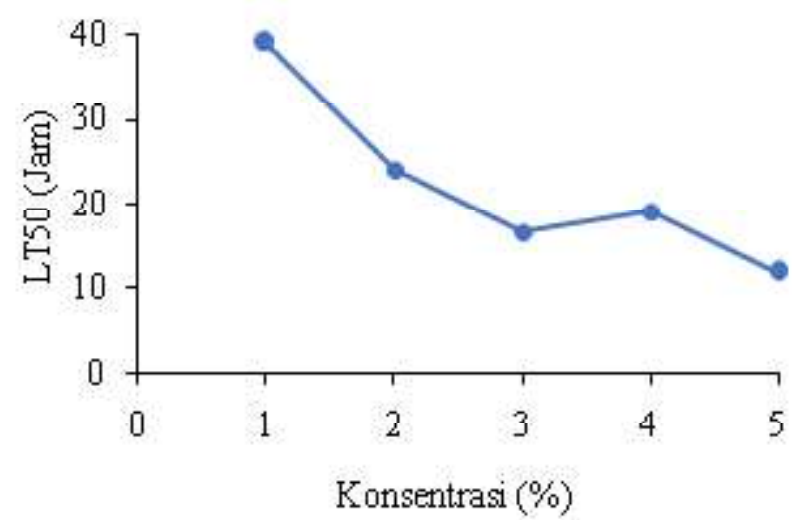

Gambar 3. Nilai Lethal Time (LT) 50 pada Konsentrasi Ekstrak Daun Mengkudu terhadap Mortalitas Larva $C$. binotalis 
serangga uji $\left(\mathrm{LT}_{50}\right)$ pada 38,89 jam untuk perlakuan konsentrasi $1 \%$ dan 11,85 jam untuk $5 \%$.

\section{DAFTAR PUSTAKA}

Cahyono, B. 1995. Cara Meningkatkan Budidaya Kubis. Yayasan Pustaka Nusantara. Yogyakarta. 86 hlm.Hasibuan, R. 2012. Insektisida Pertanian. Lembaga Penelitian Universitas Lampung. Bandar Lampung, $57 \mathrm{hlm}$.

Hasibuan, R. 2012. Insektisida Pertanian. Lembaga Penelitian Universitas Lampung. Bandar Lampung, $57 \mathrm{hlm}$.

Kardinan, A. 2004. Pestisida Nabati. Penebar Swadaya, Jakarta.

Kaswinarni F. 2005. Toksisitas dan Pengaruh Konsentrasi Sub Letal Ekstrak Pacar Cina (Aglaia odorata Lour.) Terhadap Pertumbuhan Ulat Krop Kubis (Crocidolomia binotalis Zeller). Skripsi. Semarang: Fakultas Matematika dan Ilmu Pengetahuan Alam Universitas Diponegoro.

Mursito, B. 2002. Ramuan Tradisional. Cetakan 1. Penebar Swadaya. Jakarta. 24 hal.
Natawigena, H, H., 1993. Dasar-Dasar Perlindungan Tanaman. Trigenda Karya. Bandung.

Pracaya, 2006. Kol alias kubis. Penebar swadaya. Jakarta.

Rueda A, AM Shelton. 2006. Diamondback Moth (DBM). ww.nysaes.cornell.edu . htm.

Sembel, D. T. 2010. Pengendalian Hayati HamaHama Serangga Tropis dan Gulma. Andi. Yogyakarta.

Sunardi. 2001. Pengaruh Penggunaan Patogen Steinernema carpocopsae terhadap Populasi Hama Plutella xylostella pada Tanaman Kubis (Brassica oleracea var. Capitatal). Jurnal Ilmiah Inovasi Politeknik Pertanian Negeri Jember. 1(3) : 32-41.

Suryaningsih, E., dan Hadisoeganda. 2004. Pestisida Botani Untuk Mengendalikan Hama dan Penyakit Pada Sayuran. Balai Penelitian Tanaman Sayuran. Pusat Penelitian dan Pengembangan Hortikultura. Balai Penelitian dan Pengembangan Pertanian, Bandung. 